$\begin{array}{cc}\text { ACADEMIA ROMÂNĂ } & \text { Rev. Roum. Chim., } \\ \text { Reve, 65(6), 579-585 } \\ \text { http://web.icf.ro/rrch/ } & \text { DOI: 10.33224/rrch.2020.65.6.08 } \\ & \end{array}$

Dedicated to Professor Ion Grosu on the occasion of his 65 th anniversary

\title{
NEW STABLE 2,3-DICHLORO,1,3-DIPHOSPHAPROPENES; SYNTHESIS AND CHARACTERIZATION
}

\author{
Raluca SEPTELEAN, ${ }^{a}$ Alexandra MURESAN, ${ }^{a}$ Albert SORAN ${ }^{b}$, \\ Ionut-Tudor MORARU ${ }^{\mathrm{a}}$ and Gabriela NEMES ${ }^{\mathrm{a},{ }^{*}}$
}

\begin{abstract}
${ }^{a}$ Faculty of Chemistry and Chemical Engineering, Department of Chemistry, METALOMICA Research Centre, Babeș-Bolyai University, 11 Arany Janos, 400028 Cluj-Napoca, ROUMANIA

${ }^{b}$ Faculty of Chemistry and Chemical Engineering, Department of Chemistry, Supramolecular Organic and Organometallic Chemistry Centre (SOOMCC), Babeș-Bolyai University, 11 Arany Janos, 400028 Cluj-Napoca, ROUMANIA
\end{abstract}

Two novel diphosphapropenic compounds bearing two vicinal chlorine atoms on the $\mathrm{P}=\mathrm{C}-\mathrm{P}$ moiety have been obtained and completely characterized both through experimental (multinuclear NMR, HRMS, $\mathrm{X}$-ray diffraction) and theoretical methods. These compounds are, due to their multiple coordination sites and the two halogen atoms, very interesting building blocks for new organometallic, cumulenic and coordination derivatives.

\section{INTRODUCTION}

The chemistry of unsaturated compounds containing the phosphaalkenyl $-\mathrm{P}=\mathrm{C}<$ moiety maintains its scientific interest due to the applications of these compounds, especially in obtaining coordinative compounds with applications in catalysis. ${ }^{1,2}$ If the symmetric carbodiphosphiranes with the general formula $\mathrm{R}_{3} \mathrm{P}=\mathrm{C}=\mathrm{PR}_{3}$ (where $\mathrm{R}$ is a bulky organic group) are well represented in the literature, ${ }^{3-7}$ the unsymmetrical derivatives containing a bicoordinated trivalent and a tricoordinated pentavalent phosphorus atom namely diphosphapropenes containing the $\mathrm{P}=\mathrm{C}-\mathrm{P}(=\mathrm{E})$ backbone (when $\mathrm{E}$ is a group 16 element) are less studied. ${ }^{8}$ Almost unknown remain 2,3-dihalogenated,1,3-diphosphapropenic derivatives, which represent effective building blocks for the synthesis of new organometallic and coordination compounds due to multiple reaction centers: the electron lone pairs, the halogen atoms and also the $\mathrm{P}=\mathrm{C}$ double bond. In this respect, some phosphaalkenylphosphine oxides or thioxides $\mathrm{Mes} * \mathrm{P}=\mathrm{C}(\mathrm{Cl})-\mathrm{PCl}(=\mathrm{E}) \mathrm{R} \quad(\mathrm{E}=\mathrm{O}, \mathrm{S}$, $\mathrm{R}=$ Mes* $^{*}$ (2,4,6-tri-tert-butylphenyl), $\left.\mathrm{tBu}\right)$ were prepared and used as monodentate or chelating ligands,${ }^{9}$ but their reactivity is yet to be established.

In order to stabilize the $\mathrm{P}=\mathrm{C}$ double bond by kinetic protection, the bulky organic group 2,4,6tritertbutylphenyl (Mes*) is the substituent of choice to be used on the phosphorus atom of the

* Corresponding author: gabriela.nemes@ubbcluj.ro 
phosphaalkenyl unit. ${ }^{7-13}$ However, when used for stabilizing $\mathrm{P}=\mathrm{C}=\mathrm{P}=\mathrm{O}$ cumullenic unit, a cyclisation of the supermesityl group was observed, even at low temperature, by addition of a methyl group from an ortho-tertbutyl unit to the $\mathrm{C}=\mathrm{P}$ double bond of the $\mathrm{C}=\mathrm{P}=\mathrm{O}$ moiety, forming a five member saturated cycle. ${ }^{8}$ This behavior of the supermesityl group challenged as to find different stabilizing groups that offer sufficient steric hindrance but do not allow the cyclization of the cumullenic unit.

A theoretical study revealed that the presence of bulky organic groups connected to the $\mathrm{P}(\mathrm{V})$ atom induce a stabilizing effect but their electronic effects also play an important role in the stabilization of such compounds. ${ }^{14,15}$ For example the silyl group connected on the $\mathrm{P}(\mathrm{V})$ atom increases the stability of $\mathrm{RP}=\mathrm{C}=\mathrm{P}(=\mathrm{E}) \mathrm{R}$ derivatives. In contrast, the presence of electronwithdrawing groups leads to the decrease of the bond order in the $-\mathrm{C}=\mathrm{P}(=\mathrm{E})$ fragment.

Following the research in this area, we present here the synthesis and complete characterization of two new 2,3-dichlorinated,1,3-diphosphapropenes bearing as stabilizing unit on the pentavalent phosphorus atom a 2,4,6-tri-iso-propylphenyl group in order to prevent the previously observed cyclisation and thus being able to act better as ligands for metals.

\section{RESULTS AND DISCUSSION}

Following a procedure similar to that previously used for the preparation of diphosphapropenic system containing a $\mathrm{P}=\mathrm{C}-\mathrm{P}(\mathrm{E})$ backbone, ${ }^{9}$ the preparation of the 3-chloro(\{chloro[(2,4,6-tri-tert-butylphenyl)phosphanylidene]methyl $\}$ )[2,4,6-tris(propan2-yl)phenyl]- $\lambda^{5}$-phosphanethione 3 (Mes* $\mathrm{P}=\mathrm{C}(\mathrm{Cl})$ $\mathrm{P}(\mathrm{S})(\mathrm{Cl})$ Trip) (Scheme 1) was achieved in two stages: the synthesis of the new diphosphapropene Mes ${ }^{*} \mathrm{P}=\mathrm{C}(\mathrm{Cl})-\mathrm{P}(\mathrm{Cl})$ Trip 2 chloro( $\{$ chloro[(2,4,6-tritert-butylphenyl)phosphanylidene]methyl $\})[2,4,6-$ tris-propan-2-yl)phenyl]phosphane followed by its oxidation with sulfur.

In the first step, the new derivative 2 was obtained by the addition of an equivalent of a phosphaalkenyllithium Mes* $\mathrm{P}=\mathrm{CClLi}$ to a solution of 2,4,6-tri-isopropyl-dichlorophosphine at low temperature, as shown in the Scheme 1.

The diphosphapropene 2, separated from the reaction mixture by filtration in pentane, was obtained as yellow crystals from diethyl ether. The newly formed compound was found to be air sensitive (it decomposes fast in reaction with water or air) giving rise to a large number of decomposition compounds which could not be separated from the reaction mixture and characterized. 2 was completely characterized in solution through multinuclear spectroscopy and mass spectrometry. In the ${ }^{31} \mathrm{P}$ and ${ }^{31} \mathrm{P}\{\mathrm{H}\}$ NMR spectra two doublets were observed at $83.9(\mathrm{P}-\mathrm{C})$ and $278.8(\mathrm{P}=\mathrm{C})$ ppm with a ${ }^{2} J_{P P}$ coupling constant of $125.2 \mathrm{~Hz}$, in the expected ranges for phosphorus atoms involved in a $\mathrm{P}=\mathrm{C}-\mathrm{P}$ unit when compared to similar compounds. ${ }^{9}$ In the ${ }^{13} \mathrm{C}\{\mathrm{H}\}$ NMR, the central carbon atom of the $\mathrm{P}=\mathrm{C}-\mathrm{P}$ unit gives rise to a resonance signal at $155.5 \mathrm{ppm}$, as a doublet of doublets (with ${ }^{2} J_{P C}$ coupling constants of 77.3 and $89.1 \mathrm{~Hz}$ ). All the resonance signals from the ${ }^{1} \mathrm{H}$ and ${ }^{13} \mathrm{C}\{\mathrm{H}\}$ NMR were assigned using twodimensional experiments and show the nonequivalency of the carbon atoms of the supermesityl and tri-iso-propyl groups due to a hindered rotation.

The selective oxidation of derivative 2 with sulfur in refluxing toluene afforded the novel 2,3dichloro,3-thio,1,3-diphosphapropene (Scheme 1). The reaction undergoes with an almost quantitative conversion when using $100 \%$ excess of sulfur and was found to be complete after 48 hours (monitored through ${ }^{31} \mathrm{P}$ NMR).

The new diphosphapropene $\mathbf{3}$ was separated after removal of excess sulfur (by precipitating it in pentane) as yellow crystals in diethyl ether. The derivative $\mathbf{3}$ is completely stable in argon and does not decompose at short exposures to air/moisture (decomposition products were observed only after exposure longer than 2 weeks). The structure of compound $\mathbf{3}$ was completely characterized in solution, through multinuclear NMR spectroscopy and mass spectrometry and in solid state, by X-ray diffraction.

The ${ }^{31} \mathrm{P}$ NMR spectrum reveals two doublet signals, high field shifted when compared to those observed for the precursor 2 , at $79.5(\mathrm{C}-\mathrm{P}=\mathrm{S})$ and $322.8(\mathrm{P}=\mathrm{C})$ with a ${ }^{2} J_{P P}$ coupling constant of 134.9 $\mathrm{Hz}$. The ${ }^{1} \mathrm{H}$ and ${ }^{13} \mathrm{C}\{\mathrm{H}\}$ spectra show the specific resonance signals of all the protons and carbon atoms at the expected chemical shifts ${ }^{9}$ and their complete assignation was possible after 2D experiments. For instance, the central carbon atom of the $\mathrm{P}=\mathrm{C}-\mathrm{P}(=\mathrm{S})$ moiety gives rise to a doublet of doublets at $160.0 \mathrm{ppm}\left({ }^{2} J_{P C}=67.5\right.$ and $\left.85.0 \mathrm{~Hz}\right)$. A close analysis of the NMR data revealed that the rotation of both aromatic groups (supermesityl and tri-iso-propylphenyl) is hindered, causing the nonequivalence of the carbon and proton atoms as further detailed in the experimental part. 
<smiles>CC(C)(C)c1cc(C(C)(C)C)c(P=C(Cl)Cl)c(C(C)(C)C)c1</smiles>

Scheme 1

Single crystals of $\mathbf{3}$ were obtained by recrystallization from diethylether. One crystal was mounted on a MiTeGen microMount cryoloop and data was collected on a Bruker D8 VENTURE diffractometer using Mo-K $\alpha$ radiation $(\lambda=0.71073 \AA)$ from a $\mathrm{I} \mu \mathrm{S} 3.0$ micro focus source with multilayer optics, at low temperature $(100 \mathrm{~K})$. Further details on the data collection and refinement methods can be found in Table 1 and the experimental section.
Compound $\mathbf{3}$ crystallizes in the triclinic centrosymmetric space group with two molecules in the unit cell, related through an inversion center. Although one of the phosphorus atoms is chiral, the X-ray diffraction revealed that both the $R_{P}$ and $S_{P}$ isomers are found in the crystal in equal proportions, thus the crystal is actually a solid racemic mixture. The asymmetric unit consists of only one molecule (Figure 1).

\section{Table 1}

Crystal data and structure refinement for compound $\mathbf{3}$

\begin{tabular}{|c|c|}
\hline Compound & 3 \\
\hline Empirical formula & $\mathrm{C}_{34} \mathrm{H}_{52} \mathrm{Cl}_{2} \mathrm{P}_{2} \mathrm{~S}$ \\
\hline Formula weight & 625.65 \\
\hline Crystal size /(mm) & $0.174 \times 0.059 \times 0.020$ \\
\hline Crystal habit & light yellow needle \\
\hline Wavelength $(\AA)$ & 0.71073 \\
\hline Temperature (K) & $100 .(2)$ \\
\hline Crystal system & Triclinic \\
\hline Space group & $\mathrm{P}$ \\
\hline $\mathrm{a}(\AA)$ & $6.2264(9)$ \\
\hline $\mathrm{b}(\AA)$ & $16.857(2)$ \\
\hline $\mathrm{c}(\AA)$ & $18.519(3)$ \\
\hline $\mathrm{a}\left({ }^{\circ}\right)$ & $66.614(5)$ \\
\hline $\mathrm{b}\left(\left(^{\circ}\right)\right.$ & $89.771(5)$ \\
\hline $\mathrm{g}\left({ }^{\circ}\right)$ & $81.688(5)$ \\
\hline Volume $\left(\AA^{3}\right)$ & $1762.3(4)$ \\
\hline$Z$ & 2 \\
\hline Density (calculated) $\left(\mathrm{g} \mathrm{cm}^{-3}\right)$ & 1.179 \\
\hline Absorption coefficient $\left(\mathrm{mm}^{-1}\right)$ & 0.355 \\
\hline$F(000)$ & 672 \\
\hline$\theta$ range for data collections $\left(^{\circ}\right)$ & $2.23-25.05$ \\
\hline $\mathrm{T}_{\max } / \mathrm{T}_{\min }$ & $0.647 / 0.746$ \\
\hline Reflections collected & 45288 \\
\hline Independent reflections, $R_{\text {int }}$ & $6236,0.0407$ \\
\hline Completeness to $\theta=25.05^{\circ}$ & $99.7 \%$ \\
\hline Refinement method & Full-matrix least-squares on $\mathrm{F}^{2}$ \\
\hline Data / restraints / parameters & $6236 / 0 / 367$ \\
\hline Goodness-of-fit on $\mathrm{F}^{2}$ & 1.181 \\
\hline Final $R$ indicies $[I>2 \sigma(I)]$ & $R_{l}=0.0601$ \\
\hline \multirow{3}{*}{$R$ indices (all data) } & $w R_{2}=0.1410$ \\
\hline & $R_{l}=0.0646$ \\
\hline & $w R_{2}=0.1424$ \\
\hline Largest diff. peak and hole, $\mathrm{eA}^{-3}$ & $0.887,-0.493$ \\
\hline CCDC No. & 1962766 \\
\hline
\end{tabular}




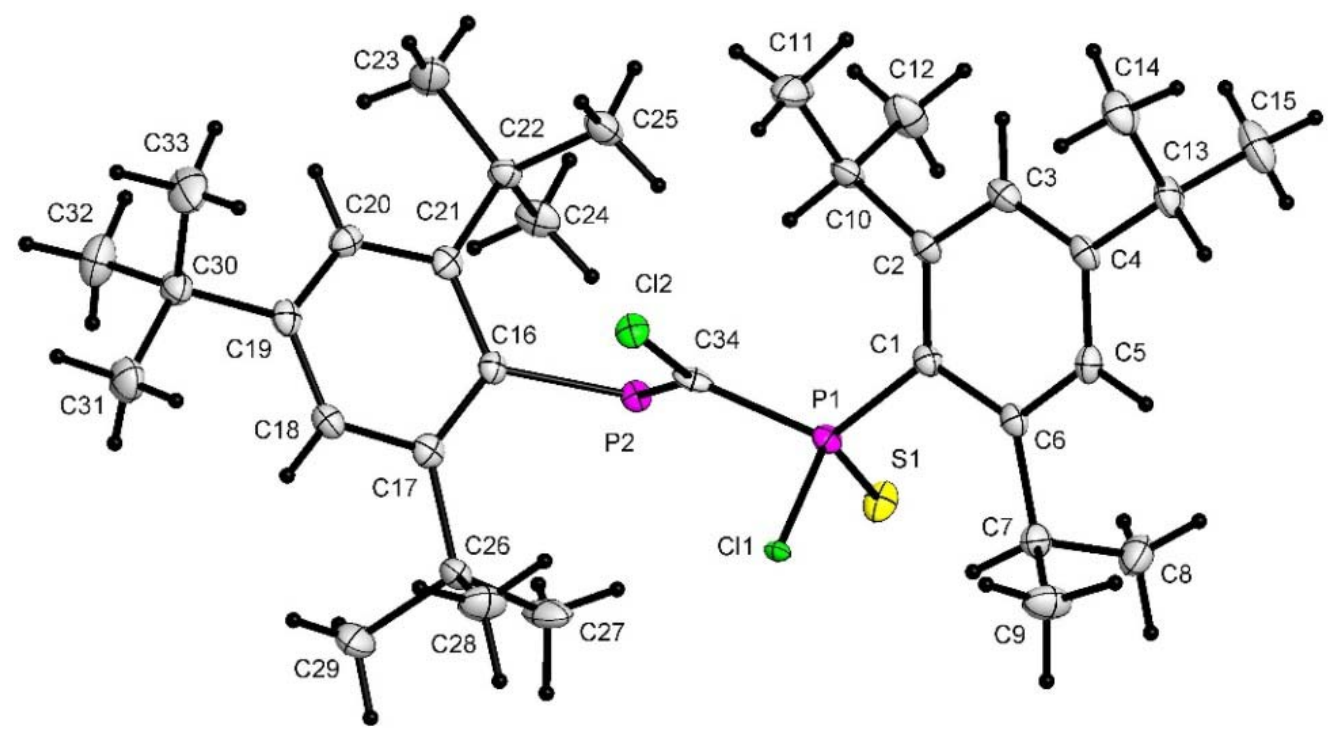

Fig. 1 - View of the $(R)_{\mathrm{P} 1}$ isomer in the asymmetric unit in the crystal of $\mathbf{3}$, shown with $50 \%$ probability ellipsoids.

Table 2

Selected bond lengths $(\AA)$ and angles $\left(^{\circ}\right)$ for compound $\mathbf{3}$

\begin{tabular}{cccc}
\hline Mes*(C)-P & $1.846(4)$ & Mes*(C)-P=C & $101.4(2)$ \\
$\mathbf{P}=\mathbf{C}$ & $1.687(4)$ & $\mathbf{P}=\mathbf{C}-\mathbf{P}$ & $127.4(3)$ \\
$\mathbf{C}-\mathbf{C l}$ & $1.720(4)$ & $\mathbf{P}=\mathbf{C}-\mathbf{P}$ & $115.8(2)$ \\
$\mathbf{C}-\mathbf{P}$ & $1.825(5)$ & $\mathbf{C l}-\mathbf{C}-\mathbf{P}$ & $116.0(2)$ \\
$\mathbf{P}-\mathbf{C l}$ & $2.108(1)$ & $\mathbf{C}-\mathbf{P}-\mathbf{C l}$ & $94.8(1)$ \\
$\mathbf{P}=\mathbf{S}$ & $1.925(1)$ & $\mathbf{S}=\mathbf{P}-\mathbf{C}) \mathbf{C}$ - & $114.5(1)$ \\
$\mathbf{P}-\mathbf{C}$ (C)Trip & $1.831(4)$ & Mes*(C)-P=C-Cl & $-7.6(3)$ \\
& & Mes*(C)-P=C-P & $161.9(2)$ \\
& & $\mathbf{C l}-\mathbf{C}-\mathbf{P}-\mathbf{C l}$ & $55.1(2)$ \\
\hline
\end{tabular}

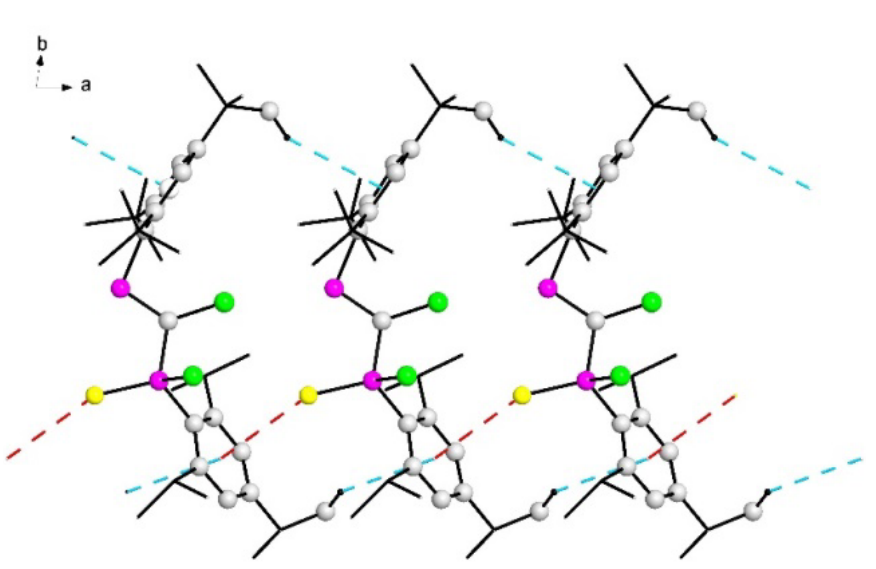

(a)

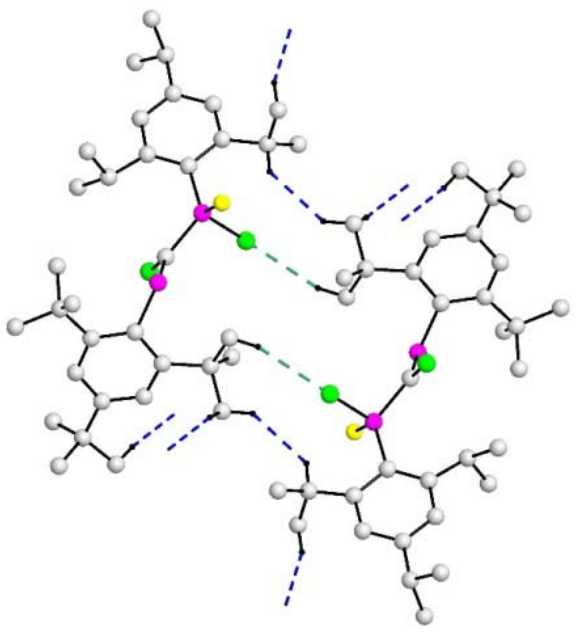

(b)

Fig. 2 - Intermolecular associations in the crystal of 3, through (a) $S \cdots \pi$ (red fragmented lines) and $\tilde{\mathrm{C}} \mathrm{H} \cdots \pi \cdot \pi$ (sky blue fragmented lines) contacts between $(R)_{\mathrm{P} 1}$ isomers, (phosphorus atoms are highlighted in magenta, the sulfur atoms in yellow, the chlorine atoms in green, and the carbon ones in clear gray); (b) $\tilde{\mathrm{C}} \mathrm{H} \cdots \mathrm{Cl}$ (green fragmented lines) and dispersive type $\mathrm{C}-\mathrm{H} \cdots \cdot \mathrm{H}-\mathrm{C}$ interactions (dark blue fragmented line) between $(R)_{\mathrm{P} 1}$ and $(S)_{\mathrm{P} 1}$ isomers. Hydrogen atoms not involved in such interactions are omitted for clarity.

In the asymmetric unit the two chlorine atoms are in a gauche arrangement, with the C11-P1-C34-Cl2 dihedral angle of 55.1(2) ${ }^{\circ}$. More geometrical parameters related to the asymmetric unit are given in Table 2. 
Table 3

Intermolecular contacts for compound $\mathbf{3}$

\begin{tabular}{|c|c|c|c|}
\hline 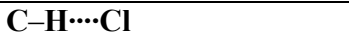 & $d_{1}(\AA)$ & $\gamma\left({ }^{\circ}\right)$ & D \\
\hline $\mathrm{C} 27-\mathrm{H} 27 \mathrm{~B} \cdots \mathrm{Cl1}^{\mathrm{a}}$ & 2.94 & 161.5 & $3.88(1)$ \\
\hline 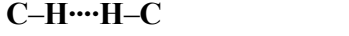 & d $(\AA)$ & $\alpha\left(^{\circ}\right)$ & $\beta\left(^{\circ}\right)$ \\
\hline $\mathrm{C} 7-\mathrm{H} 7 \cdots \cdot \mathrm{H} 29 \mathrm{C}^{\mathrm{a}}-\mathrm{C} 29^{\mathrm{a}}$ & 2.50 & 140.8 & 139.2 \\
\hline $\mathrm{C} 8-\mathrm{H} 8 \mathrm{C} \cdot \cdots \cdot \mathrm{H} 8 \mathrm{C}^{\mathrm{b}}-\mathrm{C} 8^{\mathrm{b}}$ & 2.45 & 151.5 & 151.5 \\
\hline $\mathrm{C} 29-\mathrm{H} 29 \mathrm{~A} \cdots \mathrm{H} 31 \mathrm{~B}^{\mathrm{c}}-\mathrm{C} 31^{\mathrm{c}}$ & 2.36 & 161.0 & 170.7 \\
\hline 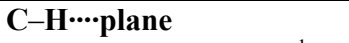 & $d_{0}(\AA)$ & $\alpha\left(^{\circ}\right)$ & $\mathbf{D}_{\text {pln }}(\AA)$ \\
\hline C33-H33B $\cdots C(16-21)^{d}$ & 0.63 & $121.5(3)$ & 3.12 \\
\hline 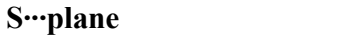 & $\mathrm{d}_{0}(\AA)$ & $\alpha\left({ }^{\circ}\right)$ & $\mathrm{D}_{\mathrm{pln}}(\AA)$ \\
\hline $\mathrm{S} 1 \cdots \cdot \mathrm{C}(1-6)^{\mathrm{c}}$ & 0.53 & $123.0(1)$ & 3.46 \\
\hline
\end{tabular}

Symmetry equivalent atoms are given by: a) $-x, 1-y, 1-z ; b) 1-x,-y, 1-z ; c)-1+x, y, z ; d) 1+x, y, z$

Close inspection of the crystal packing in the search of intermolecular interactions has concluded that all existing interactions are really weak compared to the Van der Waals radii, ${ }^{16}$ due probably to the bulkiness of the substituted aryl groups which prevents molecules from getting closer. Thus, no $\pi \cdots \pi$ or $\mathrm{Cl} \cdots \pi$ interactions were found considering a $4.1 \AA$ cutoff for the $C g \cdots C g$ and $C g \cdots \mathrm{Cl}$ distances, where $C g$ is the center of gravity of the $\mathrm{C}_{6} \mathrm{H}_{2}$ aromatic groups. ${ }^{15,17}$ Also, no $\mathrm{Cl} \cdots \mathrm{Cl}$ intermolecular interactions were found in the crystal lattice. ${ }^{18}$ However, weak $\mathrm{S} \cdots \pi$ and $\mathrm{C}-\mathrm{H} \cdots \pi$ interactions between same type of enantiomers were identified (Figure 2a). ${ }^{19,20}$ Considering only these interactions a chain like arrangement of molecules results. (Figure 2a).

In the crystal lattice further associations through $\mathrm{C}-\mathrm{H} \cdots \mathrm{Cl}$ and dispersive type, $\mathrm{C}-\mathrm{H} \cdots \mathrm{H}-\mathrm{C}$ interactions between $R_{\mathrm{P} 1}$ and $S_{\mathrm{P} 1}$ isomers were found (Figure $2 b){ }^{20-22}$ When all these weak interactions (table 3) are considered a tridimensional supramolecular network results.

Relevant information regarding the weak intermolecular contacts is given in Table 3 .

Additionally, a DFT study was performed on the diphosphapropenic moiety in order to determine additional structural and electronic properties.
Calculated structural features for species 2, 3 and 4 (4 represent the calculated specie Mes $* \mathrm{P}(\mathrm{S})=\mathrm{C}(\mathrm{Cl})$ $\mathrm{PCl}$ )Trip) are presented in Table 4. In the case of $\mathbf{3}$, a good agreement between calculated geometrical features and the experimental measured ones is observed (see Tables 2 and 4 for comparisons), while for 2 , calculations reassemble previously reported crystallographic data for similar systems. ${ }^{8,913}$ The Wiberg bond indices (WBI) are additionally illustrated for selected chemical bonds. NPA charges computed within the framework of the Natural Bond Orbital (NBO) analysis are also displayed for the $\mathrm{P}$ and $\mathrm{C}$ atoms (Table 4), highlighting an enhanced electrophilic character for the $\mathrm{P}$ atoms. Concerning the lone pair electrons (LP) on the two $\mathrm{P}$ atoms, NBO calculations reveal a mixed $s-p$ AO character in all cases (about $55-65 \% s$ and $45-35 \% p$ ), as previously revealed in other theoretical studies. ${ }^{14}$ In addition, the molecular structure of system $\mathbf{4}$ was investigated by DFT calculations, in order to assess the relative stability of the species with the $\mathrm{P}=\mathrm{S}$ bond involving the $s p^{2} \mathrm{P}$ atom related to the experimental observed derivative 3. Nonetheless, computed enthalpies indicate a higher stability for $\mathbf{3}$, with a calculated gap $\left(\Delta \mathrm{H}_{3-4}\right)$ of about $5 \mathrm{kcal} \mathrm{mol}^{-1}$.

Table 4

Selection of calculated structural features for derivatives 2,3 and calculated 4 . The WBI indices are displayed for selected chemical bonds. The calculated NPA charges for the $\mathrm{P}$ and $\mathrm{C}$ atoms of the $\mathrm{P}=\mathrm{C}-\mathrm{P}$ unit are additionally presented

\begin{tabular}{|c|c|c|c|c|c|c|c|c|c|c|c|c|}
\hline & $\begin{array}{c}\mathbf{P}-\mathbf{C}-\mathbf{P} \\
\left({ }^{\circ}\right)\end{array}$ & $\begin{array}{c}P=C \\
(\AA)\end{array}$ & $\begin{array}{c}\text { WBI } \\
(P=C)\end{array}$ & $\begin{array}{l}\mathbf{C}-\mathbf{P} \\
(\AA)\end{array}$ & $\begin{array}{c}\text { WBI } \\
(\mathbf{P}-\mathbf{C})\end{array}$ & $\begin{array}{c}\mathbf{P}-\mathbf{C l} \\
(\AA)\end{array}$ & $\begin{array}{c}\text { WBI } \\
(\mathbf{P}-\mathrm{CI})\end{array}$ & $\begin{array}{c}\mathbf{P}=\mathbf{S} \\
(\AA)\end{array}$ & $\begin{array}{c}\text { WBI } \\
(P=S)\end{array}$ & $q \mathbf{P}\left(s p^{3}\right)$ & $q \mathrm{P}\left(s p^{2}\right)$ & $q \mathrm{C}$ \\
\hline 2 & 120.6 & 1.684 & 1.58 & 1.811 & 0.95 & 2.077 & 0.88 & - & - & 0.86 & 0.73 & -0.88 \\
\hline 3 & 119.7 & 1.680 & 1.59 & 1.816 & 0.83 & 2.059 & 0.82 & 1.926 & 1.50 & 1.27 & 0.78 & -0.92 \\
\hline 4 & 127.8 & 1.675 & 1.34 & 1.815 & 0.91 & 2.080 & 0.89 & 1.924 & 1.50 & 0.88 & 1.18 & -0.95 \\
\hline
\end{tabular}


Due to the relatively high stability of the obtained compounds, they could not only be completely characterized, but are also very suitable to be tested in order to determine their coordination capacity.

\section{EXPERIMENTAL}

All the reactions have been carried out under inert conditions (argon) using Schlenk techniques. The solvents were used after purification through an MBraun automatic solvent purifying system and the THF was freshly distilled over $\mathrm{Na}$ /benzophenone. NMR experiments were performed on a Bruker Avance $400 \mathrm{MHz}$ spectrometer in $\mathrm{CDCl}_{3}$ at the following frequencies: 400.13 (reference TMS) for ${ }^{1} \mathrm{H} ; 100.61$ $\mathrm{MHz}$ (reference TMS) for ${ }^{13} \mathrm{C} ; 161.98 \mathrm{MHz}$ (reference $\mathrm{H}_{3} \mathrm{PO}_{4}$ ) for ${ }^{31} \mathrm{P}$. High resolution mass spectra were obtained using a LTQ ORBITRAP XL spectrometer (ThermoScientific) using an atmospheric pressure chemical ionization (APCI) probe.

For structure solving and refinement of the X-ray structure the Bruker APEX3 software package was used. ${ }^{23}$ The structure was solved by dual methods (SHELXT-2014/5) 24 $^{24}$ and refined by full matrix least-squares procedures based on $F^{2}$ with all measured reflections (SHELXL-2018/3). ${ }^{25}$ The structure was refined with anisotropic thermal parameters for non-H atoms. Hydrogen atoms were placed in fixed, idealized positions and refined with a riding model and a mutual isotropic thermal parameter. The drawings were created with the Diamond program. ${ }^{26}$ The supplementary crystallographic data for this paper can be obtained free of charge from The Cambridge Crystallographic Data Centre via www.ccdc.cam.ac.uk/ data_request/cif.

All theoretical calculations were performed using the Gaussian 09 package, ${ }^{27}$ in the framework of the Density Functional Theory (DFT). Geometry optimizations were performed in the gas phase without symmetry constrains. The $\mathrm{PBE}^{28}$ hybrid functional was employed in all cases, along with the Def2-TZVP ${ }^{29,30}$ basis set. Optimization criteria were set to tight, while the integration grid used was of 99 radial shells and 950 angular points for each shell $(99,950)$, precisely the "ultrafine" grid within Gaussian 09. Frequency analyses were performed in order to characterize the nature of the stationary points, and to compute the enthalpies for the investigated species. Natural Bond Orbital (NBO) $)^{31-33}$ analyses were carried out on the optimized structures. The natural charges computed within the framework of the Natural Population Analysis (NPA) and the Wiberg bond indices (WBI) are discussed throughout this text. The NBO 7.0 Program $^{34}$ was used for all NBO calculations.

Synthesis of $\mathrm{Mes} * \mathrm{P}=\mathrm{C}(\mathrm{Cl})-\mathrm{P}(\mathrm{Cl}) \mathrm{Trip}$ (2) A solution of $n$ butyllithium in hexane $(2.27 \mathrm{M}, 3.22 \mathrm{~mL}, 7.3 \mathrm{mmol})$ was added dropwise to a solution of $\mathrm{Mes} * \mathrm{P}=\mathrm{CCl}_{2}(2.79 \mathrm{~g}, 7.3 \mathrm{mmol})$ in THF $(40 \mathrm{~mL})$ at $-80{ }^{\circ} \mathrm{C}$ and was stirred for an additional hour at the same temperature. The resulting solution was transferred to a solution of $\mathrm{TripPCl}_{2}(2.37 \mathrm{~g}, 7.3 \mathrm{mmol})$ in THF $(40 \mathrm{~mL})$ at $-80^{\circ}$ $\mathrm{C}$. The brown reaction mixture was allowed to slowly warm to room temperature. After removal of volatile compounds under reduced pressure, pentane was added over the solid and the lithium salts were removed by filtration. The compound $\mathbf{2}$ was separated as a brown powder from pentane at low temperature $\left(3 \mathrm{~g}, \eta=70 \%\right.$, m.p. $\left.=167^{\circ} \mathrm{C}\right)$.
${ }^{1} \mathrm{H} \mathrm{NMR}\left(\mathrm{CDCl}_{3}, 400.13 \mathrm{MHz}\right): \delta(\mathrm{ppm})=1.28, \mathrm{~d},{ }^{3} J_{\mathrm{H}, \mathrm{H}}=$ $6.9 \mathrm{~Hz}, 6 \mathrm{H}, \mathrm{CH}_{3}$-para-isopropyl; 1.31 and $1.33 \mathrm{~d},{ }^{3} J_{\mathrm{H}, \mathrm{H}}=2.6$ and $4.2 \mathrm{~Hz}, 12 \mathrm{H}, \mathrm{CH}_{3}$-ortho-isopropyl; $1.34, \mathrm{~s}, 9 \mathrm{H}, \mathrm{CH}_{3}$-paratertbutyl; 1.43 and $1.47, \mathrm{~s}, 18 \mathrm{H}, \mathrm{CH}_{3}$-ortho-tertbutyl; 2.92, septet, ${ }^{3} J_{H, H}=6.8 \mathrm{~Hz}, 1 \mathrm{H}, \mathrm{CH}-$ para-isopropyl; 3.86, septet, ${ }^{3} J_{H, H}=6.1 \mathrm{~Hz}, 2 \mathrm{H}, \mathrm{CH}$-ortho-isopropyl; 7.10, d, ${ }^{4} J_{\mathrm{P}, \mathrm{H}}=2.9$ $\mathrm{Hz}, 2 \mathrm{H}, H_{\text {arom }}$-Trip; 7.42, d, ${ }^{4} J_{\mathrm{P}, \mathrm{H}}=4.7 \mathrm{~Hz}, 2 \mathrm{H}, H_{\text {arom }}$-Mes*

${ }^{31} \mathrm{P}$ NMR $\left(\mathrm{CDCl}_{3}, 161.98 \mathrm{MHz}\right): \delta(\mathrm{ppm})=83.9, \mathrm{~d},{ }^{2} J_{\mathrm{P}, \mathrm{P}}=$ 125.2 Hz, Trip- $\underline{P}-\mathrm{C}, 278.8, \mathrm{~d},{ }^{2} J_{\mathrm{P}, \mathrm{P}}=125.2 \mathrm{~Hz}, \mathrm{Mes}^{*}-\underline{P}=\mathrm{C}$.

${ }^{13} \mathrm{C}\{\mathrm{H}\}$ NMR $\left(\mathrm{CDCl}_{3}, 100.61 \mathrm{MHz}\right): \delta(\mathrm{ppm})=23.8, \mathrm{~d}$, ${ }^{6} J_{\mathrm{P}, \mathrm{C}}=2.2 \mathrm{~Hz}, \mathrm{CH}_{3}$-para-isopropyl; 25.2 and $25.6 \mathrm{CH}_{3}$-orthoisopropyl; 31.5, $\mathrm{CH}_{3}$-para-tertbutyl; 32.1 and 32.4, $\underline{\mathrm{C}}\left(\mathrm{CH}_{3}\right)_{2}$ ortho-isopropyl; 32.7 and $32.9, \mathrm{~d},{ }^{4} J_{\mathrm{P}, \mathrm{C}}=6.1 \mathrm{~Hz}$ and ${ }^{4} J_{\mathrm{P}, \mathrm{C}}=$ $6.7 \mathrm{~Hz}, \mathrm{CH}_{3}$-ortho-tertbutyl; 34.4, $\underline{\mathrm{CH}}\left(\mathrm{CH}_{3}\right)_{2}$-para-isopropyl, 35.2, $\underline{\mathrm{C}}\left(\mathrm{C}_{3}\right)_{3}$-para-tertbutyl; 37.9 and $38.1, \underline{\mathrm{C}}\left(\mathrm{CH}_{3}\right)_{3}$-orthotertbutyl; 122.0 and $122.6, \mathrm{C}_{\text {meta }}-\mathrm{Mes}^{*} ; 123.0, \mathrm{~d},{ }^{3} J_{\mathrm{P}, \mathrm{C}}=4.4 \mathrm{~Hz}$, $\mathrm{C}_{\text {meta }}$-Trip; 126.7, d,d ${ }^{1} J_{\mathrm{P}, \mathrm{C}}=45.5 \mathrm{~Hz},{ }^{3} J_{\mathrm{P}, \mathrm{C}}=10.0 \mathrm{~Hz}, \mathrm{C}_{\text {ipso }}{ }^{-}$ Trip , 135.6, d, ${ }^{1} J_{\mathrm{P}, \mathrm{C}}=63.0 \mathrm{~Hz}, \mathrm{C}_{\text {ipso }}-\mathrm{Mes}^{*}, 151.1, \mathrm{C}_{\text {para }}$-Mes*, $153.1, \mathrm{~d},{ }^{2} J_{\mathrm{P}, \mathrm{C}}=1.6 \mathrm{~Hz}, \mathrm{C}_{\text {ortho }}$-Trip, $153.3, \mathrm{~d},{ }^{4} J_{\mathrm{P}, \mathrm{C}}=4.3 \mathrm{~Hz}$, $\mathrm{C}_{\text {para }}$-Trip, 155.5, d, ${ }^{2} J_{\mathrm{P}, \mathrm{C}}=18.9 \mathrm{~Hz}, \mathrm{C}_{\text {ortho }}$-Mes* ${ }^{*}, 172.3$, dd, ${ }^{1} J_{\mathrm{P}, \mathrm{C}}=77.3 \mathrm{~Hz},{ }^{1} J_{\mathrm{P}, \mathrm{C}}=89.1 \mathrm{~Hz}, \mathrm{P}=\underline{\mathrm{C}}-\mathrm{P}$.

HRMS (APCI) $\left(\mathrm{C}_{34} \mathrm{H}_{52} \mathrm{Cl}_{2} \mathrm{P}_{2}\right)$ : calculated [M+1] 593.29996, found 593.29857.

Synthesis of Mes*P=C(Cl)-P(Cl)(S)Trip (3) An excess of sulfur $(0.25 \mathrm{~g}, 7.82 \mathrm{mmol})$ was added to a solution of 1,3diphosphapropene $2(2.32 \mathrm{~g}, 3.91 \mathrm{mmol})$ in toluene $(50 \mathrm{~mL})$ and the mixture was heated under reflux for 5 days. The reaction was stopped when the conversion reached $100 \%$ (monitored through ${ }^{31} \mathrm{P}\{\mathrm{H}\} \mathrm{NMR}$ ). The solvent was removed under vacuum and compound $\mathbf{3}$ was obtained by recrystallization from diethyl ether as a yellow precipitate $\left(1.54 \mathrm{~g}, \eta=63 \%\right.$, m.p. $\left.=187^{\circ} \mathrm{C}\right)$.

${ }^{1} \mathrm{H}$ NMR $\left(\mathrm{CDCl}_{3}, 400.13 \mathrm{MHz}\right): \delta(\mathrm{ppm})=1.23-1.26, \mathrm{~m}$, $18 \mathrm{H}, \mathrm{CH}_{3}$-isopropyl (ortho and para); $1.35, \mathrm{~s}, 9 \mathrm{H}, \mathrm{CH}_{3}$-paratertbutyl; $1.52, \mathrm{~d},{ }^{5} J_{P, H}=11.8 \mathrm{~Hz}, 18 \mathrm{H}, \mathrm{CH}_{3}$-ortho-tertbutyl; 2.87 , septet, ${ }^{3} J_{H, H}=11.8 \mathrm{~Hz}, 1 \mathrm{H}, \mathrm{CH}$-para-isopropyl; 3.92, septet, ${ }^{3} J_{H, H}=11.8 \mathrm{~Hz}, 2 \mathrm{H}$, CH-ortho-isopropyl; 7.09, d, ${ }^{4} J_{\mathrm{P}, \mathrm{H}}=6.0 \mathrm{~Hz}, 2 \mathrm{H}, H_{\text {arom }}$-Trip; 7.45, d, ${ }^{4} J_{\mathrm{P}, \mathrm{H}}=14.4 \mathrm{~Hz}, 2 \mathrm{H}$, $H_{\text {arom }}-\mathrm{Mes}^{*}$.

${ }^{31} \mathrm{P}$ NMR $\left(\mathrm{CDCl}_{3}, 161.98 \mathrm{MHz}\right): \delta(\mathrm{ppm})=79.5, \mathrm{~d}$, ${ }^{2} J_{\mathrm{P}, \mathrm{P}}=134.9 \mathrm{~Hz}$, Trip- $\underline{P}-\mathrm{C} ; 322.8, \mathrm{~d},{ }^{2} J_{\mathrm{P}, \mathrm{P}}=134.9 \mathrm{~Hz}$, Mes $* P=\mathrm{C}$

${ }^{13} \mathrm{C}\{\mathrm{H}\}$ NMR $\left(\mathrm{CDCl}_{3}, 100.61 \mathrm{MHz}\right): \delta(\mathrm{ppm})=23.7, \mathrm{~d}$, ${ }^{6} J_{\mathrm{P}, \mathrm{C}}=3.0 \mathrm{~Hz}, \mathrm{CH}_{3}$-para-isopropyl; 24.6 and $25.2 \underline{\mathrm{CH}}_{3}$-orthoisopropyl; 31.4, $\underline{\mathrm{CH}}_{3}$-para-tertbutyl; $32.0, \mathrm{~d},{ }^{3} \mathrm{~J}_{\mathrm{P}, \mathrm{C}}=6.8 \mathrm{~Hz}$, $\mathrm{CH}\left(\mathrm{CH}_{3}\right)$-ortho-isopropyl; 33.6 and $33.8, \mathrm{~d},{ }^{4} J_{\mathrm{P}, \mathrm{C}}=7.6 \mathrm{~Hz}$ and ${ }^{4} J_{\mathrm{P}, \mathrm{C}}=6.7 \mathrm{~Hz}, \underline{\mathrm{CH}}_{3}$-ortho-tertbutyl; 34.2, $\underline{\mathrm{C}} \mathrm{H}_{\left(\mathrm{CH}_{3}\right)_{2} \text {-para- }}$ isopropyl, $35.1 \quad \underline{\mathrm{C}}\left(\mathrm{CH}_{3}\right)_{3}$-para-tertbutyl, 38.0 and 38.7 $\underline{\mathrm{C}}\left(\mathrm{CH}_{3}\right)_{3}$-ortho-tertbutyl; 122.2 and $123.9 \mathrm{C}_{\text {meta }}$-Mes*; 123.3, $\mathrm{d},{ }^{3} J_{\mathrm{P}, \mathrm{C}}=13.5 \mathrm{~Hz} \mathrm{C}_{m e t a}$-Trip; $128.9, \mathrm{~d},{ }^{1} J_{\mathrm{P}, \mathrm{C}}=98.1 \mathrm{~Hz} \mathrm{C}_{i p s}{ }^{-}$ Trip; 151.5, $\mathrm{C}_{\text {para }}$-Mes*; 152.4, d, ${ }^{2} J_{\mathrm{P}, \mathrm{C}}=13.4 \mathrm{~Hz}, \mathrm{C}_{\text {ortho }}$-Trip; $152.8, \mathrm{~d},{ }^{4} J_{\mathrm{P}, \mathrm{C}}=3.2 \mathrm{~Hz}, \mathrm{C}_{\text {para }}$-Trip; 154.2 and $154.0 \mathrm{~d},{ }^{2} J_{\mathrm{P}, \mathrm{C}}=$ $3.2 \mathrm{~Hz}$ and ${ }^{2} J_{\mathrm{P}, \mathrm{C}}=2.4 \mathrm{~Hz}, \mathrm{C}_{\text {ortho }}-\mathrm{Mes}^{*} ; 160.0, \mathrm{dd},{ }^{1} J_{\mathrm{P}, \mathrm{C}}=67.5$ $\mathrm{Hz},{ }^{1} J_{\mathrm{P}, \mathrm{C}}=85.0 \mathrm{~Hz} \mathrm{P}=\underline{\mathrm{C}}-\mathrm{P}$.

HRMS (APCI) $\left(\mathrm{C}_{34} \mathrm{H}_{52} \mathrm{Cl}_{2} \mathrm{P}_{2} \mathrm{~S}\right):$ calculated [M+1] 625.27203, found 625.26688.

\section{CONCLUSIONS}

We obtained two novel dichlorinated 1,3diphosphapropenes Mes* $\mathrm{P}=\mathrm{C}(\mathrm{Cl})-\mathrm{P}(\mathrm{Cl})$ Trip and Mes $* \mathrm{P}=\mathrm{C}(\mathrm{Cl})-\mathrm{P}(=\mathrm{S})(\mathrm{Cl})$ Trip (Mes ${ }^{*}=2,4,6$-tri-tert- 
butylphenyl, Trip=2,4,6-tri-iso-propylphenyl). The newly obtained compounds proved to be stable for an indefinite time under argon and for several days in air/mosture. By using Trip instead of Mes* on the pentavalent phosphorus atom, the cyclization of the supermesityl group was prevented, as not to block the $\mathrm{P}(\mathrm{V})$ atom for potential future applications. These compounds are valuable building blocks as they have the lone pairs on the phosphorus and/or sulfur atoms, the double bond and the chlorine atoms available for modifications in view of future applications.

Acknowledgements. This work was supported by a grant of Ministry of Research and Innovation, CNCS - UEFISCDI, project number PN-III-P4-ID-PCE-2016- 0351, within PNCDI III, Romania. We thank also the National Centre for X-ray Diffraction (CNDRX) at Babeș-Bolyai University for providing access to $\mathrm{X}$-ray diffraction facilities.

\section{REFERENCES}

1. H. Liang, S. Ito and M. Yoshifuji, Org. Lett., 2004, 6, 452427.

2. S. Ito, H. Liang, M. Yoshifuji, J. Organomet. Chem., 2005, 690, 2531-2535.

3. M. Yoshifuji, K. Toyota and N. Inamoto, J. Chem. Soc., Chem. Commun., 1984, 689-690.

4. R. Appel, P. Fölling, B. Josten, M. Siray, V. Winkhaus and F. Knoch, Angew. Chem., Int. Ed. Engl., 1984, 23, 618-619.

5. M. Gouygou, M. Koenig, J. Escudié and C. Couret, Heteroat. Chem., 1991, 2, 221-227.

6. M. Yoshifuji, S. Sasaki and N. Inamoto, J. Chem. Soc., Chem. Commun., 1989, 1732-1733.

7. S. Ito, K. Nishide and M. Yoshifuji, Organometallics, 2006, $25,1424-1430$.

8. R. Septelean, H. Ranaivonjotovo, G. Nemes, J. Escudie, I. Silaghi-Dumitrescu, H. Gornitzka, L. Silaghi-Dumitrescu and S. Massou, Eur. J. Inorg. Chem., 2006, 4237-4241.

9. R. Septelean, G. Nemes, J. Escudie, I. Silaghi-Dumitrescu, H. Ranaivonjatovo, P. Petrar, H. Gornitzka, L. SilaghiDumitrescu and N. Saffon, Eur. J. Inorg. Chem., 2009, 5 , 628-654.

10. H. Liang, K. Nishide, S. Ito and M. Yoshifuji, Tetrahedron Lett., 2003, 44, 8297-8300.

11. S. Ito, H. Liang and M. Yoshifuji, Chem. Commun., 2003, 398-399.

12. K. Nishide, H. Liang, S. Ito and M. Yoshifuji, J. Organomet. Chem., 2005, 690, 4809-4815.

13. G. Cretiu Nemes, H. Ranaivonjatovo, J. Escudie, I. SilaghiDumitrescu, L. Silaghi-Dumitrescu and H. Gornitzka, Eur. J. Inorg. Chem., 2005, 1109-1113.

14. R. A. Septelean, P. M. Petrar, G. Nemes, J. Escudié and I. Silaghi-Dumitrescu, Phosphorus Sulfur Silicon Relat Elem., 2011, 186, 2321-2331.

15. R. Septelean, P. M. Petrar and G. Nemes, Studia UBB Chemia, 2011, 54, 131-141.
16. S. Alvarez, Dalton Trans., 2013, 42, 8617-8636.

17. C. A. Hunter and J. K. M. Sanders, J. Am. Chem. Soc., 1990, 112, 5525-5534.

18. V. R Hathwar, S. Mohana Roopan, R. Subashini, F. Nawaz Khan and T. N. Guru Row, J. Chem. Sci., 2010, 122, 677685.

19. H. Matter, M. Nazar, S. Güssregen, D. W. Will, H. Schreuder, A. Bauer, M. Urmann, K. Ritter, M.Wagner and V. Wehner, Angew. Chem., Int. Ed., 2009, 48, 2911-2916.

20. G. R. Desiraju and T. Steiner, "The Weak Hydrogen Bond in Structural Chemistry and Biology", Oxford University Press: Oxford, United Kingdom, 1999.

21. D. Danovich, S. Shaik, F. Neese, J. Echeverría, G. Aullón and S. Alvarez, J. Chem. Theory Comput., 2013, 9, 19771991.

22. C. F. Matta, J. Hernandez-Trujillo, T.-H. Tang and R. F. W. Bader, Chem. Eur. J., 2003, 9, 1940-1951.

23. Bruker (2012). APEX3, Bruker AXS Inc., Madison, Wisconsin, USA.

24. G. M. Sheldrick, Acta Crystallogr. A, 2015, 71, 3-8.

25. G. M. Sheldrick, Acta Crystallogr. C, 2015, 71, 3-8.

26. H. Putz and K. Brandenburg, DIAMOND - Crystal and Molecular Structure Visualization, Crystal Impact GbR, Kreuzherrenstr. 102, 53227 Bonn, Germany, 2018.

27. M. J. Frisch, G. W. Trucks, H. B. Schlegel, G. E. Scuseria, M. A. Robb, J. R. Cheeseman, G. Scalmani, V. Barone, G. A. Petersson, H. Nakatsuji, X. Li, M. Caricato, A. Marenich, J. Bloino, B. G. Janesko, R. Gomperts, B. Mennucci, H. P. Hratchian, J. V. Ortiz, A. F. Izmaylov, J. L. Sonnenberg, D. Williams-Young, F. Ding, F. Lipparini, F. Egidi, J. Goings, B. Peng, A. Petrone, T. Henderson, D. Ranasinghe, V. G. Zakrzewski, J. Gao, N. Rega, G. Zheng, W. Liang, M. Hada, M. Ehara, K. Toyota, R. Fukuda, J. Hasegawa, M. Ishida, T. Nakajima, Y. Honda, O. Kitao, H. Nakai, T. Vreven, K. Throssell, J. A. Montgomery, Jr., J. E. Peralta, F. Ogliaro, M. Bearpark, J. J. Heyd, E. Brothers, K. N. Kudin, V. N. Staroverov, T. Keith, R. Kobayashi, J. Normand, K. Raghavachari, A. Rendell, J. C. Burant, S. S. Iyengar, J. Tomasi, M. Cossi, J. M. Millam, M. Klene, C. Adamo, R. Cammi, J. W. Ochterski, R. L. Martin, K. Morokuma, O. Farkas, J. B. Foresman and D. J. Fox, Gaussian 09, revision E.01; Gaussian, Inc.: Wallingford, CT, 2009.

28. C. Adamo and V. Barone, J. Chem. Phys., 1999, 110, 61586170.

29. A. Schafer, C. Huber and R. Ahlrichs, J. Chem. Phys., 1994, 100, 5829-5835.

30. D. Rappoport and F. Furche, J. Chem. Phys., 2010, 133, 134105.

31. F. Weinhold and C. R. Landis, "Valency and Bonding: A Natural Bond Orbital Donor-Acceptor Perspective", Cambridge Univ. Press: Cambridge, U.K., 2005.

32. F. Weinhold and C. R. Landis, "Discovering Chemistry with Natural Bond Orbitals", Wiley-Interscience: Hoboken, NJ, 2012.

33. F. Weinhold, C. R. Landis and E. G. Glendening, Int. Rev. Phys. Chem., 2016, 35, 399-440.

34. E. D. Glendening, J. K. Badenhoop, A. E. Reed, J. E. Carpenter, J. A. Bohmann, C. M. Morales, P. Karafiloglou, C. R. Landis and F. Weinhold, NBO 7.0, Theoretical Chemistry Institute, University of Wisconsin, Madison, 2018. 
